\title{
Ozone-enhanced layers in the troposphere over the equatorial Pacific Ocean and the influence of transport of midlatitude UT/LS air
}

\author{
H. Hayashi ${ }^{1}$, K. Kita ${ }^{1}$, and S. Taguchi ${ }^{2}$ \\ ${ }^{1}$ Department of Environmental Sciences, College of Science, Ibaraki University, Mito, Japan \\ ${ }^{2}$ Research Institute for Environmental Management Technology, National Institute of Advanced Industrial Science and \\ Technology (AIST), Tsukuba, Japan
}

Received: 12 October 2007 - Published in Atmos. Chem. Phys. Discuss.: 26 November 2007

Revised: 22 April 2008 - Accepted: 29 April 2008 - Published: 19 May 2008

\begin{abstract}
Occurrence of ozone $\left(\mathrm{O}_{3}\right)$-enhanced layers in the troposphere over the equatorial Pacific Ocean and their seasonal variation were investigated based on ozonesonde data obtained at three Southern Hemisphere ADditional OZonesondes (SHADOZ) sites, Watukosek, American Samoa and San Cristobal, for 6 years between 1998 and 2003. $\mathrm{O}_{3}$-enhanced layers were found in about $50 \%$ of observed $\mathrm{O}_{3}$ profiles at the three sites. The formation processes of $\mathrm{O}_{3}$-enhanced layers were investigated by meteorological analyses including backward trajectories. On numerous occasions, $\mathrm{O}_{3}$-enhanced layers resulted from the transport of air masses affected by biomass burning. The contribution of this process was about $30 \%$ at San Cristobal during the periods from February to March and from August to September, while it was relatively low, about $10 \%$, at Watukosek and Samoa. A significant number of the $\mathrm{O}_{3}$-enhanced layers were attributed to the transport of midlatitude upper-troposphere and lower-stratosphere (UT/LS) air. Meteorological analyses indicated that these layers originated from equatorward and downward transport of the midlatitude UT/LS air masses through a narrow region between high- and low-pressure systems around the subtropical jet stream. This process accounted for 50-80\% at Watukosek between May and December, about $80 \%$ at Samoa on yearly average, and $40-70 \%$ at San Cristobal between November and March, indicating that it was important for $\mathrm{O}_{3}$ budget over the equatorial Pacific Ocean.
\end{abstract}

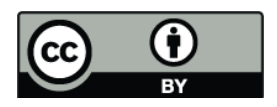

Correspondence to: $\mathrm{K}$. Kita (kita@mx.ibaraki.ac.jp)

\section{Introduction}

The tropospheric ozone $\left(\mathrm{O}_{3}\right)$ concentration in the tropics is generally low, especially over the Pacific Ocean, in comparison with that in the midlatitude (e.g., Fishman et al., 1990; Brasseur et al., 1999; Kondo et al., 2002). However, $\mathrm{O}_{3}$-enhanced layers are often observed in the tropics (e.g., Newell et al., 1996; Stoller et al., 1999; Thouret et al., 2001). Photochemical production from the $\mathrm{O}_{3}$ precursor gases emitted from biomass burning is considered to increase $\mathrm{O}_{3}$ concentrations in the tropical troposphere. Increases in $\mathrm{O}_{3}$ associated with biomass burning over the tropical Pacific Ocean have been repeatedly reported. Oltmans et al. (2001) suggested that the $\mathrm{O}_{3}$-enhanced layers observed at Fiji $\left(18.1^{\circ} \mathrm{S}, 178.2^{\circ} \mathrm{E}\right)$, Samoa $\left(14.3^{\circ} \mathrm{S}, 189.4^{\circ} \mathrm{E}\right)$, Tahiti $\left(18.0^{\circ} \mathrm{S}, 211.0^{\circ} \mathrm{E}\right)$, and Galapagos $\left(0.9^{\circ} \mathrm{S}, 270.4^{\circ} \mathrm{E}\right)$ with ozonesondes were attributable to the transport of air masses affected by biomass burning in Australia and South America. In Indonesia, during the local late dry season between September and November, enhancements of tropospheric $\mathrm{O}_{3}$ concentrations are often observed (Komala et al., 1996; Fujiwara et al., 2000), and similar $\mathrm{O}_{3}$ enhancements have also been observed in Malaysia between March and May (Yonemura et al., 2002a). Especially during El Niño periods, when severe droughts and extensive biomass burning occurred in Indonesia, remarkably large $\mathrm{O}_{3}$ increases have persisted ( $\mathrm{Fu}-$ jiwara et al., 1999; Yonemura et al., 2002b). Satellite total $\mathrm{O}_{3}$ data also showed $\mathrm{O}_{3}$ increases over the Indonesian region and the Indian Ocean during these periods (Chandra et al., 1998; Kita et al., 2000).

Transport of $\mathrm{O}_{3}$-abundant air masses is another cause of tropospheric $\mathrm{O}_{3}$ increases in the tropics. Active convection over Indonesia has been shown to carry $\mathrm{O}_{3}$ precursors to the upper troposphere, increasing the $\mathrm{O}_{3}$ concentration over

Published by Copernicus Publications on behalf of the European Geosciences Union. 


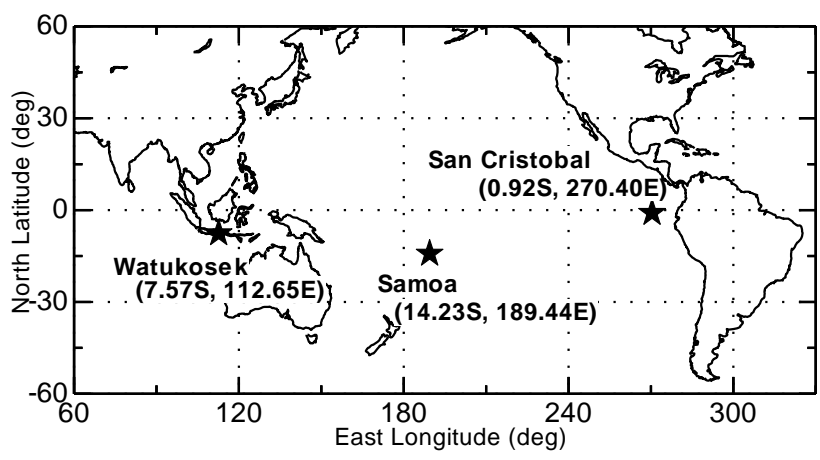

Fig. 1. The locations of the three ozonesonde stations, Watukosek, Samoa and San Cristobal, are indicated by stars.

Indonesia, the Indian Ocean and northern Australia (Kita et al., 2002). The downward transport of air masses from the upper troposphere and lower stratosphere (UT/LS) is also suggested to increase the $\mathrm{O}_{3}$ concentration in the tropics. Fujiwara et al. (1998) observed $\mathrm{O}_{3}$ enhancement in the upper troposphere at Watukosek $\left(7.57^{\circ} \mathrm{S}, 112.65^{\circ} \mathrm{E}\right)$, Indonesia and indicated that the breaking of equatorial Kelvin waves around the tropopause caused $\mathrm{O}_{3}$ transport from the stratosphere into the troposphere. Intrusions of the midlatitude UT/LS air in association with the breaking of Rossby waves around the subtropical jet stream have been suggested to cause the $\mathrm{O}_{3}$ increase as well as decrease of humidity in the tropics (e.g., Baray et al., 2000; Scott et al., 2001; Waugh and Funatsu, 2003; Waugh, 2005). Yoneyama and Parsons (1999) found extremely dry layers in the lower and middle troposphere over the tropical western Pacific Ocean, and suggested that they originated from Rossby wave breaking. Zachariasse et al. (2001) found $\mathrm{O}_{3}$ enhancement with low relative humidity (RH) in the middle troposphere over the Indian Ocean, and suggested that it was attributed to a pair of anticyclones located along the subtropical jet stream over the western Pacific and Australia. Baray et al. (1998) discussed the possible influences of tropopause foldings near the subtropical jet stream on the tropical tropospheric $\mathrm{O}_{3}$ concentrations. They showed that tongues of air mass near the subtropical jet stream with high potential vorticity (PV) values extended to the subtropical latitudes in the middle troposphere. Occurrence of intrusions of high-PV air masses, induced by wave-breaking events, were relatively high over the Pacific and Atlantic Oceans during northern winter, when westerly ducts are strongest (e.g., Postel and Hitchman, 1999; Waugh and Polvani, 2000). These studies showed that the high-PV air masses could directly intrude into latitudes of about $20^{\circ}$. However, it is not clear whether the transportation of these air masses to the equatorial region $\left(15^{\circ} \mathrm{N}-15^{\circ} \mathrm{S}\right)$ from midlatitude UT/LS directly contributes to $\mathrm{O}_{3}$ enhancement in this region. Systematic studies on the contribution of the midlatitude UT/LS air intrusions to tropospheric $\mathrm{O}_{3}$ enhancement in the equatorial region using long-term observational data have been quite limited.
In this work, 6-year ozonesonde data at three equatorial sites in the western, central and eastern Pacific Ocean were used to examine the occurrence of $\mathrm{O}_{3}$-enhanced layers in the free troposphere over this region and its seasonal variations. Contributions of biomass burning and the intrusion of midlatitude UT/LS air masses, as well as their seasonal variations, were examined. The transport process of midlatitude UT/LS air masses into the equatorial region and its importance are also discussed.

\section{Ozone and meteorological data}

In order to investigate $\mathrm{O}_{3}$-enhanced layers in the troposphere over the western, central, and eastern Pacific Ocean, we analyzed ozonesonde data obtained at three equatorial stations, Watukosek $\left(7.57^{\circ} \mathrm{S}, 112.65^{\circ} \mathrm{E}\right)$, Indonesia, American Samoa $\left(14.23^{\circ} \mathrm{S}, 189.44^{\circ} \mathrm{E}\right)$, and San Cristobal $\left(0.92^{\circ} \mathrm{S}\right.$, $\left.270.40^{\circ} \mathrm{E}\right)$, Galapagos. Figure 1 shows the location of these three sites. In general, ozonesonde observations have been regularly carried out once per week as a part of the Southern Hemisphere Additional OZonesondes (SHADOZ) experiment (Thompson et al., 2003a and b), and the data are available at the SHADOZ website (http://croc.gsfc.nasa.gov/ shadoz/). The data analyzed in this work were obtained between August 1999 and April 2002 at Watukosek, between January 1998 and March 2003 at Samoa, and between March 1998 and August 2002 at San Cristobal. Focusing on the free troposphere that is not directly affected by the stratosphere, only the $\mathrm{O}_{3}$ data obtained below $12 \mathrm{~km}$ were used in this study.

In the observation, $\mathrm{O}_{3}$ concentration and $\mathrm{RH}$ were measured with balloon-borne electrochemical concentration cell (ECC) ozonesondes (Science Pump type 6A at Samoa and San Cristobal, and ENSCI type $2 Z$ at Watukosek) with Vaisala RS-80 radiosondes (Oltmans et al., 2001; Fujiwara et al., 2003). Although $\mathrm{O}_{3}$ data were derived using MEISEI RSII-KC79D ozonesondes between May 1993 and July 1999 (Komala et al., 1996; Fujiwara et al., 2000), these data were not included in this study because RH was not measured during this period. The precision of the $\mathrm{O}_{3}$ measurements is $5-10 \%$ in the troposphere. The measured RH is valid without any corrections down to about $-30^{\circ} \mathrm{C}$ air temperature (e.g., Miloshevich et al., 2001). The vertical resolution of $\mathrm{O}_{3}$ concentration and RH is less than about $100 \mathrm{~m}$.

In order to investigate the origins and transport routes of the $\mathrm{O}_{3}$-enhanced air masses, kinematic backward/forward trajectories were calculated. In the calculation, the European Centre for Medium-Range Weather Forecast (ECMWF)/the World Climate Reseach Program (WCRP) level III-A a Tropical Ocean and Global Atmosphere (TOGA) gridded data and a computing program developed by Tomikawa and Sato (2005) were used. The spatial and temporal resolution of the used ECMWF data was $2.5^{\circ} \times 2.5^{\circ} \times 21$ levels and $12 \mathrm{~h}$, respectively. The time step for calculation was $15 \mathrm{~min}$, and the 

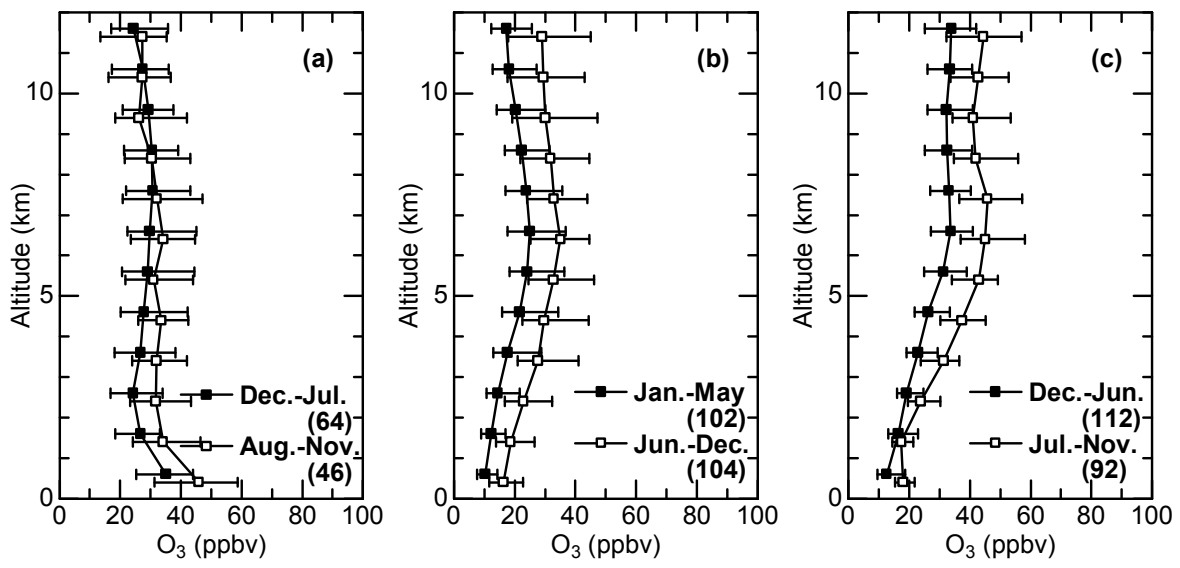

Fig. 2. Vertical profiles of median ozone mixing ratios at (a) Watukosek, (b) Samoa and (c) San Cristobal. Black and white squares indicate median values in two different periods of the year. The horizontal bars indicate the central $66.6 \%$ range for each $1-\mathrm{km}$ altitude range. The numbers in parentheses are the numbers of observational data used for calculating median values in each period.

vertical displacement of air masses was calculated using the vertical wind component of the ECMWF data.

PV was used to indicate the transport of the midlatitude UT/LS air to the equatorial region. PV values were calculated from the ECMWF operational analysis gridded data using a computing program developed by National Institute of Advanced Industrial Science and Technology (AIST). The spacial and temporal resolution of the used ECMWF data was $1.125^{\circ} \times 1.125^{\circ} \times 61$ levels and $6 \mathrm{~h}$, respectively. In this program, isentropic surface levels were evaluated from vertical temperature profiles at each grid. The horizontal wind vectors were linearly interpolated to the isentropic surfaces in the vertical direction to calculate PV values from them.

The location of convection, which can upwardly transport air in the planetary boundary layer (PBL), was inferred using outgoing longwave radiation (OLR) data. National Centers for Environmental Prediction (NCEP) operational OLR data (http://www.cdc.noaa.gov/Composites/Day/) were used in the analysis. The locations of biomass burning, which can emit $\mathrm{O}_{3}$ precursors, were shown using satellite hot-spot data (spots indicating high temperature) obtained from the World Fire Atlas provided by the European Space Agency (http://dup.esrin.esa.it/ionia/wfa/index. asp) using Along Track Scanning Radiometer (ATSR)-2 data.

\section{Results and discussion}

\subsection{The occurrence of $\mathrm{O}_{3}$-enhanced layers}

The tropospheric $\mathrm{O}_{3}$ concentrations measured at the three sites showed a seasonal variation: it was higher in the periods from August to November, June to December and July to November than the periods from December to July, January to May and December to June at Watukosek, Samoa
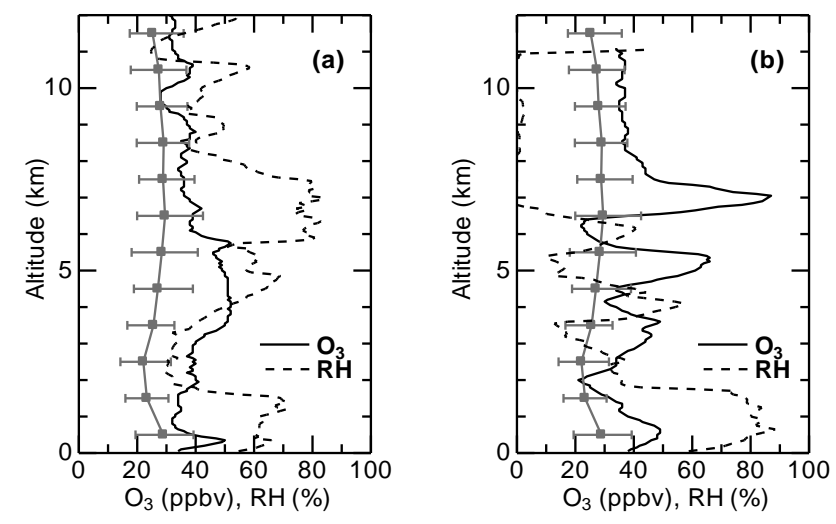

Fig. 3. Vertical profiles of $\mathrm{O}_{3}$ mixing ratio (solid line) and relative humidity (dashed line) at Watukosek (a) on 3 December 2000, and (b) on 7 June 2000. The median values of the $\mathrm{O}_{3}$ mixing ratios in the period from December to July are shown by gray squares, and their central $66.6 \%$ ranges are shown by horizontal bars.

and San Cristobal, respectively. Median values and central $66.6 \%$ ranges of the observed mixing ratios were separately calculated in each $1-\mathrm{km}$ altitude range between 0 and $12 \mathrm{~km}$ during these periods at each station, and are shown in Fig. 2. The median values of $\mathrm{O}_{3}$ mixing ratios over the equatorial Pacific Ocean were between 20 and 40 ppbv.

When the measured $\mathrm{O}_{3}$ mixing ratio exceeded its lower 83.3 percentile range in the free troposphere at altitudes below $12 \mathrm{~km}$, we regarded it as an $\mathrm{O}_{3}$-enhanced layer. If the $\mathrm{O}_{3}$ enhancement reached altitudes above $12 \mathrm{~km}$, we excluded it from this analysis because of the possibility of its being a direct influence of the tropospheric tropopause layer (TTL), which is connected to the stratosphere. $\mathrm{O}_{3}$ enhancement near the surface, probably in the PBL, was also excluded because it was considered to be a result of $\mathrm{O}_{3}$ production in the 

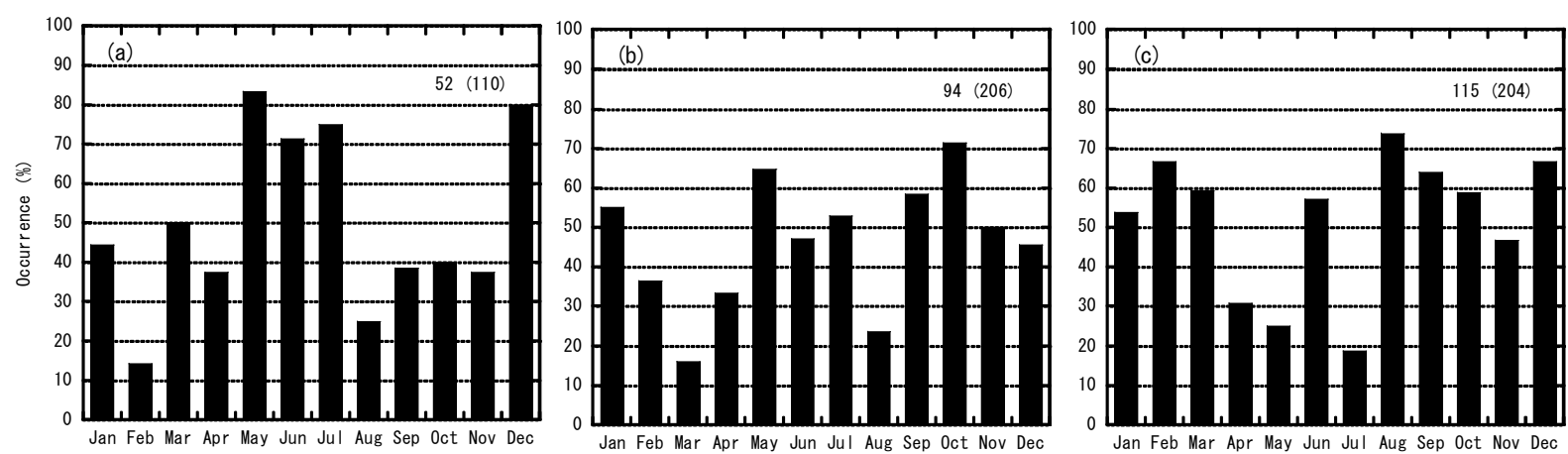

Fig. 4. Occurrence of tropospheric $\mathrm{O}_{3}$-enhanced layers at (a) Watukosek, (b) Samoa and (c) San Cristobal by month. The number shown in the upper right of each panel is the number of $\mathrm{O}_{3}$ profiles with $\mathrm{O}_{3}$-enhanced layers in the whole data period, and the number in parenthesis is the total number of observed $\mathrm{O}_{3}$ profiles.

surface-polluted air. Figure $3 \mathrm{a}$ and $\mathrm{b}$ show vertical profiles of $\mathrm{O}_{3}$ mixing ratios and $\mathrm{RH}$ at Watukosek on 3 December 2000 and on 7 June 2000 , respectively. $\mathrm{O}_{3}$ mixing ratios obviously exceeded their lower 83.3 percentile range at altitudes between 2 and $6 \mathrm{~km}$ in Fig. 3a, and at altitudes between 2.5 and $4 \mathrm{~km}$, between 4.5 and $5.5 \mathrm{~km}$ and between 6.5 and $8 \mathrm{~km}$ in Fig. 3b, and these altitude ranges are considered to be $\mathrm{O}_{3}$ enhanced layers. We excluded the cases in which the vertical thickness of the layer was less than about $1 \mathrm{~km}$, such as the layer at about $10.5 \mathrm{~km}$ in Fig. 3a, because it is difficult to investigate these small-scale events by trajectory analyses. We consider that these thin peaks are insignificant because the number of these excluded peaks accounted for only $6 \%$ of all observed $\mathrm{O}_{3}$-enhanced layers and because these layers have fewer $\mathrm{O}_{3}$ molecules than those in thick layers. The increase of $\mathrm{O}_{3}$ up to about $50 \mathrm{ppbv}$ below $1.5 \mathrm{~km}$ in Fig. $3 \mathrm{~b}$ was also excluded, because it occurred in the PBL.

Figure 4 shows the occurrence of $\mathrm{O}_{3}$-enhanced layers at the three sites by month. The number of occurrence was calculated by dividing the number of profiles where one or more $\mathrm{O}_{3}$-enhanced layers appeared by the total number of successful observations in each month. At these sites, the yearly average of the occurrence was about $50 \%$, indicating that $\mathrm{O}_{3}$-enhanced layers occurred frequently. This occurrence suggests that their formation processes are significant for the $\mathrm{O}_{3}$ budget in the equatorial Pacific region. The occurrence shows a seasonal variation. At Watukosek, it was about $40 \%$ in the periods from January to April and from August to November, while it exceeded about $70 \%$ in the other months. At Samoa, it was less than $40 \%$ between February and April, while it was about 50\% or more from May to January except for August. At San Cristobal, it was less than $30 \%$ in April, May and July, while it generally exceeded 50\% in other months. These seasonal variations are connected to the processes by which $\mathrm{O}_{3}$-enhanced layers are formed, as discussed in Sects. 3.2 and 3.3.

$\mathrm{RH}$ in the $\mathrm{O}_{3}$-enhanced layer is considered as an indicator of the vertical displacement of $\mathrm{O}_{3}$-enhanced air masses.
If an $\mathrm{O}_{3}$-enhanced air mass were raised by convection just before it was observed, its RH would be higher than those at the altitudes above and below the layer. On the contrary, if an $\mathrm{O}_{3}$-enhanced air mass was transported downward, $\mathrm{RH}$ would be lower. Especially, if the $\mathrm{O}_{3}$-enhanced air mass was transported from the UT/LS region, the RH should be very low. We found that the $\mathrm{RH}$ in more than $90 \%$ of the all $\mathrm{O}_{3}$ enhanced layers was lower than those in altitudes above and below the layer, as in the three layers shown in Fig. 3b, at all three sites. This result suggests that downward transport of air masses, such as downward transport of the UT/LS air mass, is very important for the formation of $\mathrm{O}_{3}$-enhanced layers. On the contrary, the $\mathrm{RH}$ in the $\mathrm{O}_{3}$-enhanced layer was higher than those above and below the layer in about $40 \%$ of layers found in December and January at Watukosek, and in about 20\% of layers found in March and October at San Cristobal. This result suggests that upward transport probably due to active convection may produce an $\mathrm{O}_{3}$-enhanced layer in some cases.

\subsection{The formation process of $\mathrm{O}_{3}$-enhanced layers}

\subsubsection{Biomass burning}

Transport of plumes from biomass burning and the $\mathrm{O}_{3}$ photochemical production in them is one way the $\mathrm{O}_{3}$-enhanced layers were assumed to form. As shown in Fig. 3a, an $\mathrm{O}_{3}-$ enhanced layer was observed at altitudes between 3.5 and $6 \mathrm{~km}$ at Watukosek on 3 December 2000. The RH also increased in this layer. Figure 5 shows 10-day backward trajectories calculated from nine grid points around Watukosek at $550 \mathrm{hPa}$ (about $5 \mathrm{~km}$ ) from the measurement time. A major part of the trajectories show that the air mass was transported from the boundary layer over northern Australia as shown by red curves. Higher RH in this layer is consistent with this result. Black squares in Fig. 6 show that there were many hot spots in northern and eastern Australia during the period when the trajectories passed over this region, indicating that 


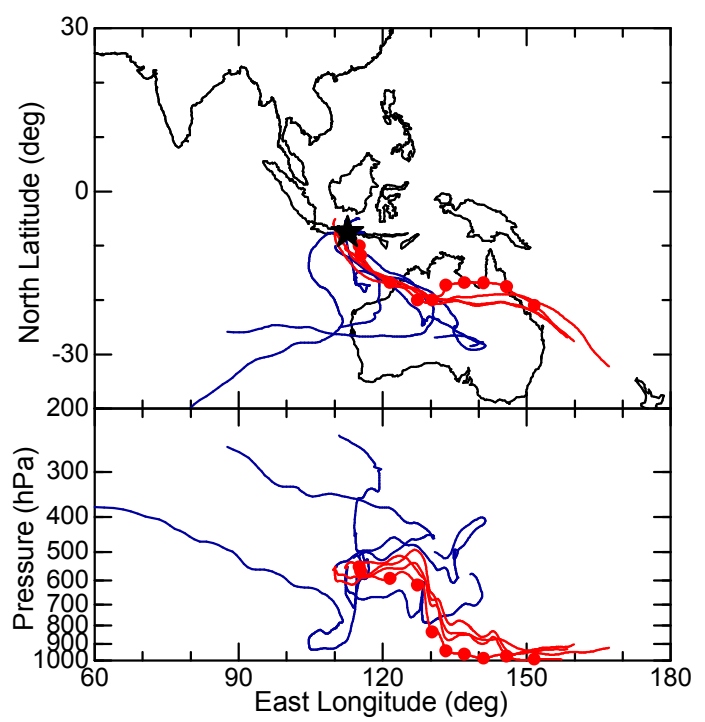

Fig. 5. Ten-day backward trajectories from Watukosek at $550 \mathrm{hPa}$ on 3 December 2000. The trajectories were calculated from 9 grid points, and the center of the grid points was over Watukosek. The spatial interval of the grid points was $2.5^{\circ}$ in latitude by $2.5^{\circ}$ in longitude. Upper and lower panels show the horizontal and vertical motion of air masses, respectively. Dots show the air mass position on a representative trajectory in each 24-h interval. Location of Watukosek is indicated by a star.

biomass burning was active there. The daily average OLR values on 30 November, when the trajectories suggested a rapid upward transport in the northern Australia, in Fig. 6 show that they were significantly low over this region, implying that active convection occurred there. These results strongly suggest that $\mathrm{O}_{3}$ precursors emitted from biomass burning over northern Australia were upwardly transported by convection over the northwest of this region, and that $\mathrm{O}_{3}$ photochemical production during the transport formed the $\mathrm{O}_{3}$-enhanced layer found over Watukosek.

In this way, we categorized the $\mathrm{O}_{3}$-enhanced layers resulting from the biomass burning by adopting following criteria: 1) a major part of the backward trajectories from the layer were passed over a convection region of low-OLR values less than about $200 \mathrm{Wm}^{-2}$,2) the backward trajectories suggests upward transport from the lower troposphere in the low-OLR region, and 3) hot-spot distribution suggests that biomass burning occurred on the windward side of the lowOLR region in the lower troposphere. We considered that significant biomass burning occurred when more than 5 hotspots were found in a $5^{\circ} \times 5^{\circ}$ area. Although the numbers in the above criteria are rather arbitrarily chosen, the result does not critically depend on them.

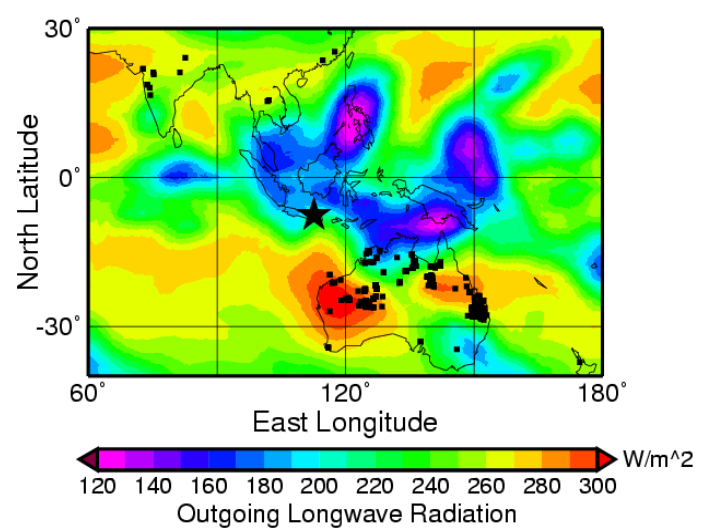

Fig. 6. A contour map of the daily average OLR value on 30 November 2000. The color bar refers to the OLR values in $\mathrm{Wm}^{-2}$. Black squares indicate the hot-spot distribution derived from the European Space Agency World Fire Atlas for the period from 24 November to 30 November 2000. Location of Watukosek is indicated by a star.

\subsubsection{Transport of midlatitude UT/LS air}

Because of the frequent stratosphere-troposphere exchange, active $\mathrm{O}_{3}$ photochemical production in the urban polluted air, and less $\mathrm{O}_{3}$ destruction due to lower water vapor concentration, the $\mathrm{O}_{3}$ concentration in the midlatitude is generally higher than that in the tropics. The transport of midlatitude UT/LS air can form $\mathrm{O}_{3}$-enhanced layers with significantly low RH in the tropical middle troposphere. As shown in Fig. 3b, $\mathrm{O}_{3}$-enhanced layers at altitudes between 2.5 and $4 \mathrm{~km}$, between 4.5 and $5.5 \mathrm{~km}$ and between 6.5 and $8 \mathrm{~km}$, were observed at Watukosek on 7 June 2000. The RH negatively correlated with $\mathrm{O}_{3}$ in these layers. Figure 7 a shows nine 10-day backward trajectories calculated from the center layer at $550 \mathrm{hPa}$ (about $5 \mathrm{~km}$ ) from the measurement time. Backward trajectories calculated from upper (about $7 \mathrm{~km}$ ) and lower (about $3.5 \mathrm{~km}$ ) layers were similar to those in Fig. 7a. The trajectories can be categorized into two groups: trajectories coming from a region along the subtropical jet stream at about $25^{\circ} \mathrm{S}$ over the Indian Ocean (shown by red curves) and those coming from eastern Indonesia/north of Australia (shown by blue curves). The former trajectories show a downward motion from about the $300 \mathrm{hPa}$ level, and the latter trajectories show an upward motion from the PBL (not shown). Low-RH values in this layer are consistent with the former trajectories, indicating that the air masses in these layers were transported eastward along the subtropical jet stream at about $25^{\circ} \mathrm{S}$ several days and were transported equatorward and downward after that.

In similar way, we categorized the $\mathrm{O}_{3}$-enhanced layer resulting from the transport of midlatitude UT/LS air by adopting the criteria: 1) a major part of backward trajectories from the layer indicated that the air masses in the layer were 

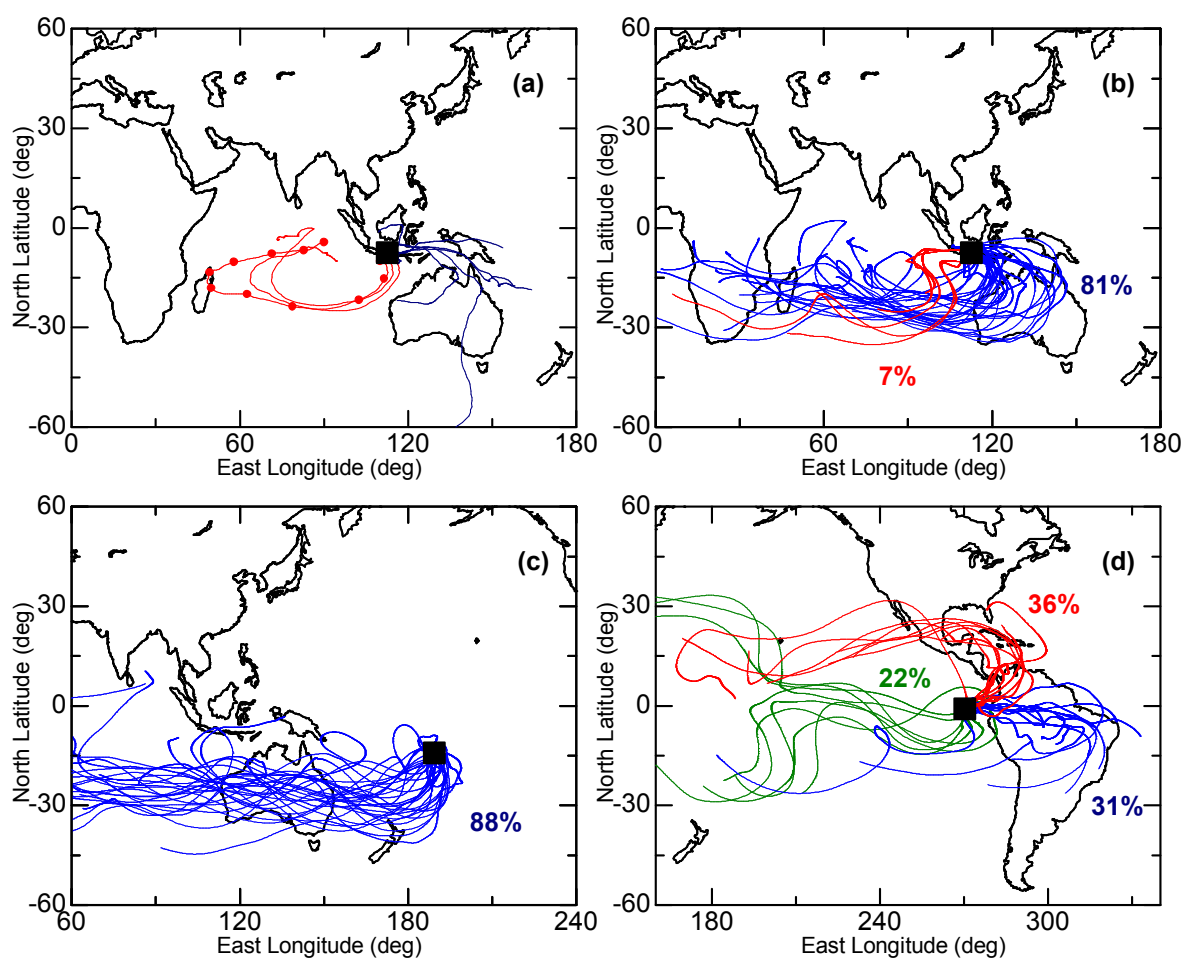

Fig. 7. Ten-day backward trajectories from the altitude of $\mathrm{O}_{3}$-enhanced layers with low relative humidity. (a) Trajectory from Watukosek on 7 June. Dots show the air mass position on a representative trajectory in each 24-h interval. (b), (c) and (d) Thirty representative trajectories tracing back to the subtropical jet stream region from Watukosek, Samoa, and San Cristobal, respectively. Blue and red curves in (b) show the trajectories classified into the transport routes as shown in Fig. 13a and b. Red, blue and green curves in (d) show the trajectories classified into the transport routes as shown in Fig. 13d, e and f, respectively. The numbers shown in (b), (c) and (d) are the percentage of "transport of midlatitude UT/LS air" cases along the route as shown in Fig. 13a-f to all "transport of midlatitude UT/LS air" cases at each station. The colors of the numbers correspond to those of the trajectory curves. Location of observational sites is indicated by a square.

transported from latitudes higher than $20^{\circ}$ near the subtropical jet stream and from UT region higher than the $300 \mathrm{hPa}$ level, which is close to the midlatitude tropopause where influence of the LS air is significant, and 2) no low-OLR (less than about $200 \mathrm{Wm}^{-2}$ ) region was found along the transport route from the subtropical jet region to the layer. The result does not critically depend on the numbers in these criteria. As shown in Sect. 3.1, $\mathrm{O}_{3}$-enhanced layers with low $\mathrm{RH}$, similar to those in Fig. 3b, accounted for about $90 \%$ of all $\mathrm{O}_{3}$ enhanced layers observed at the three sites. A significant part of these $\mathrm{O}_{3}$-enhanced layers with low $\mathrm{RH}$ were categorized into that resulting from the transport of midlatitude UT/LS air. Figure $7 \mathrm{~b}-\mathrm{d}$ show representative examples of 10-day backward trajectories calculated from these layers, showing that the high- $\mathrm{O}_{3}$, low-RH air masses observed in these layers were transported from latitudes higher than $20^{\circ}$ near the subtropical jet stream and from altitudes higher than the $300 \mathrm{hPa}$ level to the equatorial middle troposphere. No low-OLR region was found along the trajectories (not shown), implying that convection did not affect these air masses.

\subsubsection{Contribution of each formation process}

Figure 8 shows the number of $\mathrm{O}_{3}$-enhanced layers observed at Watukosek, Samoa, and San Cristobal in each month. The number of layers resulting from biomass burning is shown by black bars. The contribution of biomass burning was relatively large (about 30\%) at San Cristobal during the periods from February to April and from August to September, probably due to the influence of biomass burning in South America. At Watukosek and Samoa, it was relatively small (less than $10 \%)$. The small contribution of biomass burning in the western Pacific region was partly because biomass burning was inactive over this region including Indonesia between 1998 and 2002, when the La Niña tendency dominated. Significant $\mathrm{O}_{3}$ increases in this region were reported in the El Niño periods (Chandra et al., 1998; Fujiwara et al., 1999; Kita et al., 2000; Yonemura et al., 2002b).

Red bars in Fig. 8a-c show the number of layers resulting from the transport of midlatitude UT/LS air, indicating that this process significantly contributed to the formation of $\mathrm{O}_{3}$-enhanced layers in the equatorial Pacific region. At Watukosek, about $50-80 \%$ of the $\mathrm{O}_{3}$-enhanced layers were 

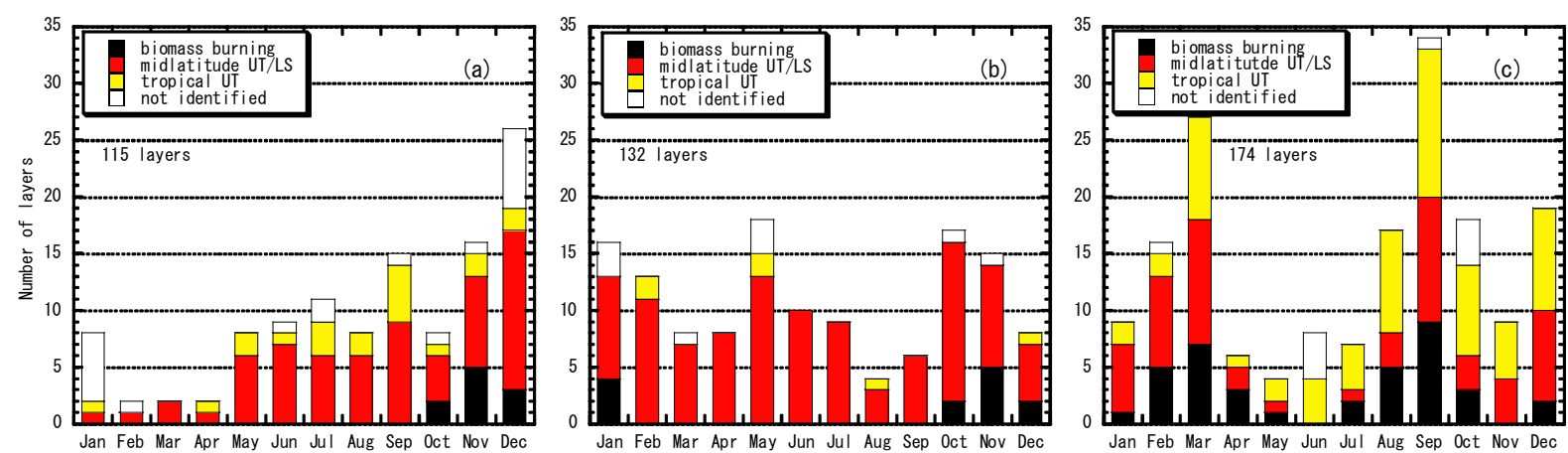

Fig. 8. Number of $\mathrm{O}_{3}$-enhanced layers by month at (a) Watukosek, (b) Samoa and (c) San Cristobal. Black, red, and yellow bars indicate the number of layers resulting from biomass burning, the transport of midlatitude UT/LS air, and the transport of tropical UT air, respectively. White bars show the number of layers whose formation process was not identified. The number shown in each panel is the total number of $\mathrm{O}_{3}$-enhanced layers.

attributed to this process in the periods from June to September and from November to December. At Samoa, this process accounted for a major part of the $\mathrm{O}_{3}$-enhanced layers throughout the year, and the contribution of this process was about $80 \%$ on yearly average. At San Cristobal, the $\mathrm{O}_{3}$ enhanced layers resulting from this process contributed about 40-70\% in the period from November to March, and about $30 \%$ between August and September. Seasonal variation in the contribution of this process would be connected with that of the transport route of the midlatitude UT/LS air, as discussed in the next section.

The formation process of the other $\mathrm{O}_{3}$-enhanced layers remains uncertain. Backward trajectories calculated from these layers show that the high- $\mathrm{O}_{3}$, low-RH air masses in these layers were often transported within tropical latitudes between $20^{\circ} \mathrm{N}$ and $20^{\circ} \mathrm{S}$ and in the UT higher than the $300 \mathrm{hPa}$ level for about a week. They did not pass over a low OLR region in this period. In these cases, the layers were categorized as "tropical UT air". As shown by yellow bars in Fig. 8a-c, it accounted for more than $30 \%$ in March and June-December periods at San Cristobal, while this category accounted for insignificant percent of all the $\mathrm{O}_{3}$-enhanced layers at Watukosek and Samoa. In this category case, the source of the $\mathrm{O}_{3}$-enhanced air masses can not be traced back by the backward trajectories. The ozone increase might be attributed to long-range transport of air masses affected by the biomass burning and by the upward transport due to convection, mixing of stratospheric air in the tropospheric tropopause layer (TTL), and nitric oxide (NO) production by lightning discharge. The rest of the $\mathrm{O}_{3}$-enhanced layers were categorized as "not identified" layers. This category included various cases. For example, backward trajectories suggest that some $\mathrm{O}_{3}$-enhanced air masses passed over a low OLR region without biomass burning area, and that other air masses were transported from lower troposphere over the tropical ocean, where $\mathrm{O}_{3}$ concentration is generally low. In some cases, transport routes of $\mathrm{O}_{3}$-enhanced air

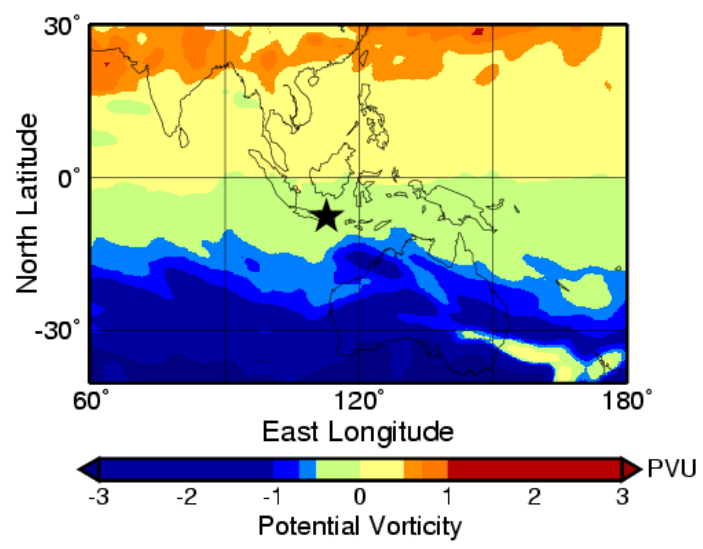

Fig. 9. A contour map of PV on the $327 \mathrm{~K}$ isentropic surface on 5 June 2000. Location of Watukosek is indicated by a star. The color bar indicates the PV values in PVU.

masses could not be identified because backward trajectories from 9 grid points around the layers diverged significantly. As shown by white bars in Fig. 8a-c, percentages of these "not identified" layers were not very large at the three sites.

\subsection{The transport process of the midlatitude UT/LS air to the equatorial region}

In order to understand the transport process of the midlatitude UT/LS air masses to the equatorial Pacific region, we investigated the transport route of the air masses and connections with the meteorological condition by using the data derived in 2000. We have adopted absolute PV $(|\mathrm{PV}|)$ values larger than $1 \mathrm{PV}$ unit (PVU: $1 \mathrm{PVU}=10^{-6} \mathrm{~m}^{2} \mathrm{~s}^{-1} \mathrm{~K} \mathrm{~kg}^{-1}$ ) to indicate the midlatitude UT/LS air. $|\mathrm{PV}|$ values about $1 \mathrm{PVU}$ are usually found in the UT region close to tropopause. "The transport of the midlatitude UT/LS air" in this study is mainly attributed to the transport of midlatitude UT air, although the cross-tropopause transport of stratospheric air 


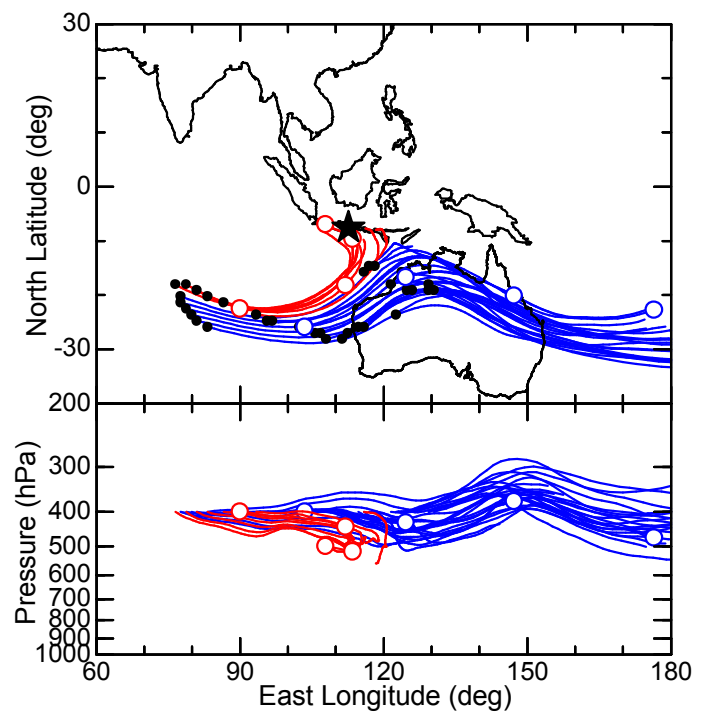

Fig. 10. Three-day forward trajectories calculated from the region of PV=-1 PVU shown in Fig. 9 on the $327 \mathrm{~K}$ isentropic surface on 5 June 2000. Open circles indicate the air mass position on representative trajectories in each 24-h interval. Location of Watukosek is indicated by a star.

may contribute to it. Figure 9 is a contour map of PV on the $327 \mathrm{~K}$ isentropic surface on 5 June 2000, 2 days before the layer was observed at Watukosek. The trajectory shown in Fig. 7a show that the air mass in the $\mathrm{O}_{3}$-enhanced layer in Fig. $3 \mathrm{~b}$ at $5 \mathrm{~km}$ was located at about $20^{\circ} \mathrm{S}$ near the subtropical jet stream at $327 \mathrm{~K}$. Although high $|\mathrm{PV}|$ (larger than $1 \mathrm{PVU}$ ) air masses projected into the tropics at about $17^{\circ} \mathrm{S}$ latitude and $120^{\circ} \mathrm{E}$ longitude, no high $|\mathrm{PV}|$ values calculated from the ECMWF data were found near the equator even when the $\mathrm{O}_{3}$-enhanced layer was observed over Watukosek.

Figure 10 shows the 3-day forward trajectories indicating the transport of $|\mathrm{PV}|=1 \mathrm{PVU}$ air masses. Black dots indicate the position of the air masses at longitudinal intervals of $1.125^{\circ}$ between $75^{\circ} \mathrm{E}$ and $130^{\circ} \mathrm{E}$ on 5 June. The trajectories calculated from these positions suggest that the transport of the midlatitude UT/LS air masses could be categorized into two groups: air masses west of $92^{\circ} \mathrm{E}$ and north of $21^{\circ} \mathrm{S}$ are transported equatorward and downward to Indonesia including Watukosek by a counterclockwise flow as shown by red curves, and the other air masses are transported eastward along the winding subtropical jet stream. The former result is consistent with the backward trajectories in Fig. 7a.

Figures 11 and 12 are wind fields and contour maps of the geopotential height at $400 \mathrm{hPa}$ on 5 June around Indonesia, respectively. They suggest that the counterclockwise flow was due to the circulation around a high-pressure system in the west of northern Australia, roughly at $\left(15^{\circ} \mathrm{S}, 95^{\circ} \mathrm{E}\right)$, and that the winding of the subtropical jet stream was due to a low-pressure system over central Australia. The equatorward trajectories show that the midlatitude UT/LS air was

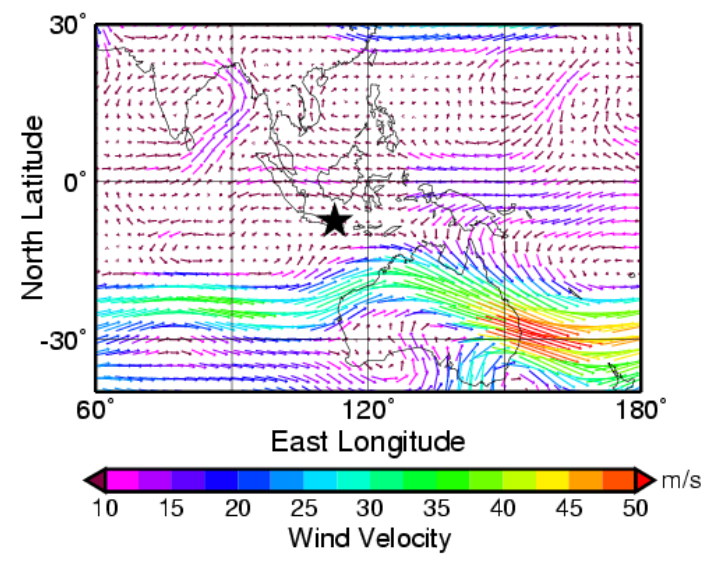

Fig. 11. A map indicating the daily average values of horizontal wind vectors at $400 \mathrm{hPa}$ on 5 June 2000 . The wind data were obtained from the NOAA-CIRES Climate Diagnostics Center (http: //www.cdc.noaa.gov/Composites/Day/). The color bar indicates the horizontal wind velocity in $\mathrm{ms}^{-1}$. Location of Watukosek is indicated by a star.

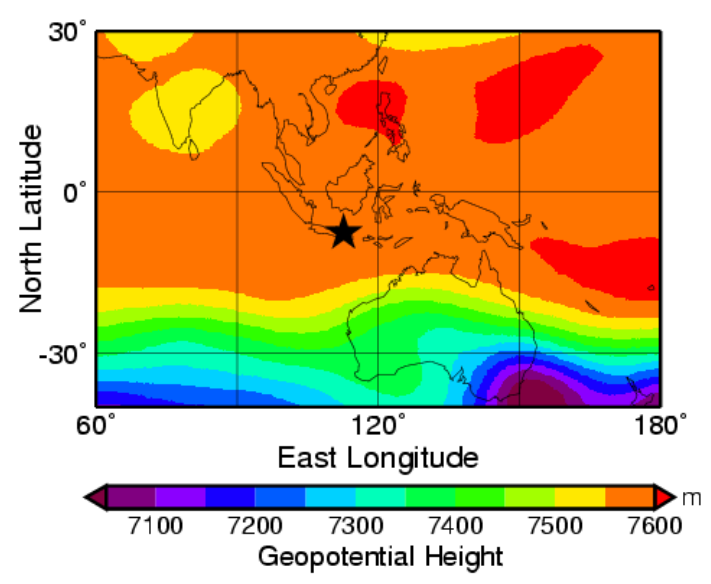

Fig. 12. A contour map indicating the daily average value of the geopotential height at $400 \mathrm{hPa}$ on 5 June 2000. The data were obtained from the NOAA-CIRES Climate Diagnostics Center (http: //www.cdc.noaa.gov/Composites/Day/). The color bar indicates the geopotential height value in $\mathrm{m}$. Location of Watukosek is indicated by a star.

transported into the equatorial region by way of a narrow region between high- and low-pressure systems. The air temperature, RH and vertical pressure velocity over the same region at the same pressure level (not shown) indicated the downward transport of dry and cold air through this region, being consistent with the downward transport of the midlatitude UT/LS air toward the equator. This meteorological condition in association with the transportation of midlatitude UT/LS air into the equatorial middle troposphere is characterized by subsiding and intrusion of a dry air mass with high $|\mathrm{PV}|$ and high $\mathrm{O}_{3}$ through the region between the 

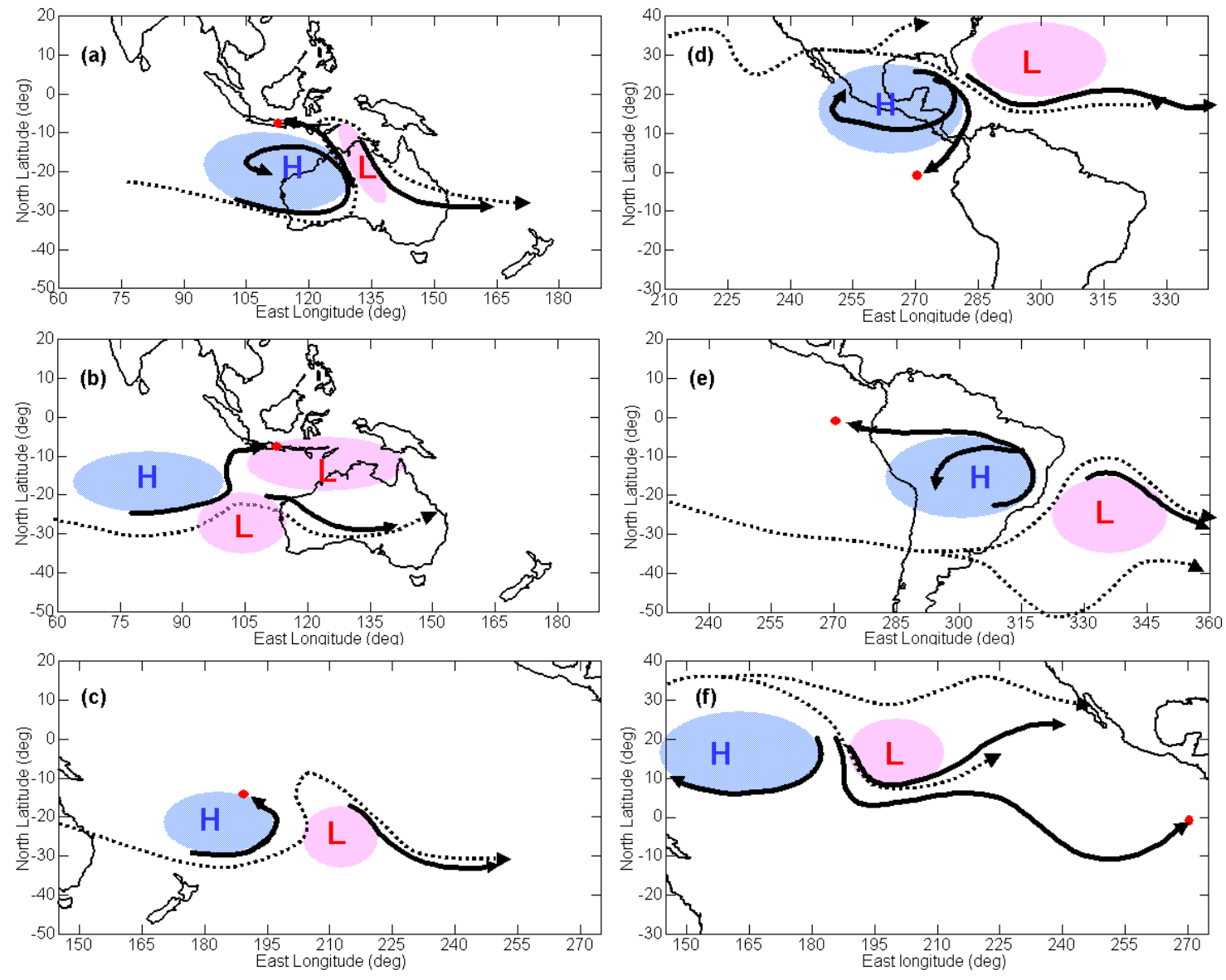

Fig. 13. Schematic illustrations of the transport processes of midlatitude UT/LS air masses to the equatorial Pacific region: (a) for Watukosek in the dry season, between June and September; (b) for Watukosek in the period from October to December; (c) for Samoa all year around; (d) for San Cristobal in the period from February to March; (e) for San Cristobal in the period from August to September; and (f) for San Cristobal in the period from November to January. Solid curves with arrows are representative examples of the forward trajectories indicating motions of $|\mathrm{PV}|=1$ PVU air masses. Red dots and dotted curves with arrows indicate the position of observational sites and the schematic path of the jet stream, respectively. The signs " $H$ " and " $L$ " indicate the rough positions of the high- and low-pressure systems which affected the transport of midlatitude UT/LS air masses to the observational sites.

high- and low-pressure systems in UT near the subtropical jet stream. It is analogous to those connected with the intrusion of stratospheric air in the midlatitude (e.g., Palmen and Newton, 1969; Waugh and Funatsu, 2003; Waugh, 2005) by Rossby wave breaking around the jet stream, although it did not necessarily lead to cross-tropopause transport of stratospheric air in this case.

Figure 13a schematically illustrates the transportation process of the midlatitude UT/LS air near Watukosek during the dry season between June and September. The solid curves with arrows are forward trajectories calculated from 13 June 2000, 1 day before an $\mathrm{O}_{3}$-enhanced layer was observed at Watukosek. During the dry season, a steady high-pressure system existed over western Australia in association with the subsidence phase of the Hadley cell. When a low-pressure system developed east of this high- pressure system in the middle- and upper-troposphere, the subtropical jet stream wound north and south as shown by the dotted curve, and the midlatitude UT/LS air mass was intruded equatorward and downward toward Watukosek through the region between the high- and low-pressure systems. Transport of the midlatitude UT/LS air along similar transport routes often occurred in the transition period from the dry season to the wet season between October and December.

Figure 13b illustrates the transportation process which sometimes occurred near Watukosek in the transition period to the wet season, between October and December. The solid curves with arrows are forward trajectories calculated from 3 December 2000, 6 days before an $\mathrm{O}_{3}$-enhanced layer was observed at Watukosek. In the wet season, a steady lowpressure system existed over northern Australia. When a high-pressure system developing over the Indian Ocean at 
about $17^{\circ} \mathrm{S}$ extended eastward and a low-pressure system developed south-east of this high-pressure system at about $28^{\circ} \mathrm{S}$, the midlatitude UT/LS air mass was intruded equatorward and downward over the Indian Ocean at about $100^{\circ} \mathrm{E}$ through the region between these high- and low-pressure systems. After that, the midlatitude UT/LS air mass was transported eastward to Watukosek by cyclonic circulation around the low-pressure system over northern Australia. From January to April, transport of the midlatitude UT/LS air seldom occurred at Watukosek, probably because the jet stream runs at latitudes considerably higher than those in the dry season.

Transport of the midlatitude UT/LS air occured more frequently at Samoa than that at the other sites, probably because it is located near the subtropical jet steam. As shown in Fig. 13c, a high-pressure system often existed over the south-west of Samoa, roughly at $175^{\circ} \mathrm{E}$, all the year around. The solid curves with arrows are forward trajectories calculated from 15 May 2000, 4 days before an $\mathrm{O}_{3}$-enhanced layer was observed at Samoa. As similar with the Fig. 13a case, the midlatitude UT/LS air mass was transported to Samoa when a low-pressure system occurred in the east of the highpressure system.

At San Cristobal, the midlatitude UT/LS air was transported from the northern or southern hemisphere, depending on the positions of the intertropical convergence zone (ITCZ) and the subtropical jet stream. Figure 13d and e are schematic illustrations of the main transportation processes of the midlatitude UT/LS air near San Cristobal in the periods from February to March, and from August to September, respectively. The solid curves in these figures are forward trajectories calculated from 18 February and $15 \mathrm{Au}-$ gust, respectively, 2000, 6 days and 9 days before an $\mathrm{O}_{3}$ enhanced layer was observed at San Cristobal. From February to March, the northern subtropical jet stream runs close to San Cristobal. When a high-pressure system existed over Central America at about $15^{\circ} \mathrm{N}$ and a low-pressure system existed north-east of the high-pressure system, the midlatitude UT/LS air was intruded equatorward and downward at around $280^{\circ} \mathrm{E}$ and was transported westward toward San Cristobal by anticyclonic circulation. Between August and September, the austral subtropical jet stream runs close to San Cristobal. When the high-pressure system existed over South America at about $15^{\circ} \mathrm{S}, 300^{\circ} \mathrm{E}$ and the low-pressure system existed in the south-east of the high-pressure system, the midlatitude UT/LS air was intruded equatorward and downward through the region between the high- and lowpressure systems around $315^{\circ} \mathrm{E}$ and was transported toward San Cristobal. Figure 13f illustrates the transportation process which often occurred in the period from November to January. The solid curves in figure are forward trajectories calculated from 5 December 2000, 9 days before an $\mathrm{O}_{3}$ enhanced layer was observed at San Cristobal. In this period, the midlatitude UT/LS air was often intruded equatorward and downward into the middle and upper troposphere through the region between high- and low-pressure systems over the northern central Pacific Ocean roughly at $20^{\circ} \mathrm{N}$ and $180^{\circ} \mathrm{E}$, or over the southern central Pacific Ocean roughly at $20^{\circ} \mathrm{S}$ and $180^{\circ} \mathrm{E}$. After the intrusion, the midlatitude UT/LS air was transported eastward to San Cristobal. This transport occurred when the westerly wind prevailed over the eastern Pacific Ocean in the equatorial UT. Longitude-time section of the 30-70 day band-pass-filtered zonal wind anomaly (not shown) shows that the intrusion of midlatitude UT/LS air, which was transported to San Cristobal in this period, mostly occurred at the transition phase of the zonal wind from easterly to westerly, suggesting that it may be related to the Madden-Julian Oscillation (MJO) in UT over the equatorial central Pacific Ocean. In May, June, and July the transport of midlatitude UT/LS air seldom occurred at San Cristobal.

As shown by example backward trajectories with different color curves in Fig. 7b-d, most cases of "transport of midlatitude UT/LS air" can be classified into the six typical transport routes shown in Fig. 13a-f. The percentage of the cases classified into each typical transport route to all "transport of midlatitude UT/LS air" cases is also indicated by numbers in Fig. 7b-d. The transport routes as shown in Fig. 13a and b accounted for $81 \%$ and $7 \%$ at Watukosek. Although the transport of midlatitude UT/LS air along the route as shown in Fig. 13b often occurred between November and December in 2000, it was transported mainly along the routes as shown in Fig. 13a in the same period of the other years. The transport routes as shown in Fig. 13c accounted for $88 \%$ at Samoa, and those as shown in Fig. 13d-f accounted for 36\%, 31\%, and $22 \%$ at San Cristobal, respectively. Seasonal variation of the occurrence of the transport of midlatitude UT/LS air, shown in Fig. 8a-c, was related to the meteorological conditions discussed above. The occurrence was relatively high in the period from May to December at Watukosek and in the three periods from February to March, from August to September, and from November to January at San Cristobal. These periods correspond to those when the transport of midlatitude UT/LS air along the routes as shown in Fig. 13a, d, $\mathrm{e}$, and $\mathrm{f}$ typically occurred.

\section{Summary and conclusions}

Ozonesonde data obtained in the western (Watukosek), central (Samoa) and eastern (San Cristobal) Pacific regions were analyzed to discuss the occurrence of $\mathrm{O}_{3}$-enhanced layers in the troposphere over the equatorial Pacific Ocean and their formation processes. The median and lower $83.3 \%$ percentile values of $\mathrm{O}_{3}$ mixing ratio between the surface and $12 \mathrm{~km}$ at three sites were between 20 and $40 \mathrm{ppbv}$ and between 30 and $55 \mathrm{ppbv}$, respectively. $\mathrm{An}_{3}$-enhanced layer was defined by $\mathrm{O}_{3}$ mixing ratios in excess of the lower $83.3 \%$ percentile range at each altitude. At the three sites, the occurrence of $\mathrm{O}_{3}$-enhanced layers was about $50 \%$ on yearly average, indicating that $\mathrm{O}_{3}$-enhanced layers occur frequently over the equatorial region. The occurrence shows a seasonal 
variation. At Watukosek, it was about $40 \%$ in the period from January to April and August to November, while it exceeded $70 \%$ in the other months. At Samoa, it was less than $40 \%$ between February and April, while it was generally $50 \%$ or more from May to January except for in August. At San Cristobal, it was less than 30\% in April, May and July, while it generally exceeded $50 \%$ in other months.

$\mathrm{O}_{3}$ photochemical production following biomass burning is one of the processes by which $\mathrm{O}_{3}$-enhanced layers are formed. Based on satellite hot-spot data, the OLR data and backward trajectory analyses, the contribution of biomass burning was estimated to be relatively high (about 30\%) at San Cristobal during the periods from February to April and August to September, probably due to the influence of biomass burning in South America. In contrast, it was relatively low (about 10\%) at Watukosek and Samoa. The latter result is at least partly because La Niña or La Niña-like conditions prevailed in the period when the analyzed data were obtained (between 1998 and 2002). During La Niña periods, biomass burning was inactive over the western Pacific region including Indonesia. Another significant process for the formation of $\mathrm{O}_{3}$-enhanced layers is the transport of midlatitude UT/LS air. A major part of $\mathrm{O}_{3}$-enhanced layers occurred with very low-RH, indicating downward displacement of the air masses and/or transport of dry air masses. Backward trajectory analyses showed that numerous dry, $\mathrm{O}_{3}$ enhanced air masses were transported from latitudes higher than $25^{\circ}$ around the subtropical jet stream region and from altitudes higher than the $300 \mathrm{hPa}$ level. This process significantly contributed to the formation of $\mathrm{O}_{3}$-enhanced layers in the equatorial Pacific region. Its contribution was 50$80 \%$ at Watukosek between May and December, about $80 \%$ at Samoa all year around, 40-70\% between November and March at San Cristobal, and about 30\% between August and September there. This result suggests that it was important for the $\mathrm{O}_{3}$ budget over the equatorial Pacific Ocean.

The transport process of the midlatitude UT/LS air toward the equatorial region has been revealed by meteorological analyses including PV and trajectories. Forward trajectories calculated from the region of $|\mathrm{PV}|=1 \mathrm{PVU}$ show that the midlatitude UT/LS air masses were drawn out from relatively narrow region between high- and low-pressure systems in the upper troposphere near the subtropical jet stream and transported to the equatorial region. These meteorological characteristics and the transportation process were analogous to those of the intrusion of stratospheric air in the midlatitude (e.g., Palmen and Newman, 1969; Waugh and Funatsu, 2003; Waugh, 2005) in association with Rossby wave breaking. Some previous studies (e.g., Baray et al., 1998; Waugh and Polvani, 2000) had already shown that the ozone increase attributable to the transport of higher $|\mathrm{PV}|$ (exceeding 1.5 PVU) air probably from the LS region occurred in the free troposphere at latitudes around $20^{\circ}$ and in the uppermost troposphere near the tropopause in equatorial region at latitudes less than $15^{\circ}$. Based on the 6-year ozonesonde data, this study shows that it is quite rare that such a high $|\mathrm{PV}|$ air is directly transported to the equatorial middle/lower-troposphere lower than $12 \mathrm{~km}$, and that significant part of the observed dry, $\mathrm{O}_{3}$-enhanced layers in this region were resulting from the transport from the midlatitude UT region.

The transport route of midlatitude UT/LS air toward Watukosek and San Cristbal differed by seasons in association with a seasonal variation of the meteorological condition. Midlatitude UT/LS air masses were transported to Watukosek along the route shown in Fig. 13a in the dry season between June and September, when stationary highpressure system exists over north-west of Australia, corresponding to the subsiding phase of the Hadley cell. They were often transported along the similar transport route with that in Fig. 13a or along other transport routes as shown in Fig. 13b in the transition period from the dry season to the wet season between October and December. During the wet season from January to April, the transport of the midlatitude UT/LS air seldom occurred around Watukosek probably because the jet stream runs at latitudes higher than those in the dry season. At San Cristobal, the midlatitude UT/LS air masses were transported from the northern hemisphere in Februrary and March and southern hemisphere in August and September, as shown in Fig. 13d and e. In these periods, the northern and southern subtropical jet stream respectively approached to equator over the American continents in association with the seasonal shift of ITCZ position. Between November and January, the midlatitude UT/LS air masses were often intruded into the equatorial middle- and uppertroposphere over the central Pacific Ocean and were transported eastward to San Cristobal, as shown in Fig. 13f. This transport route may be related with MJO.

To evaluate the contribution of the transport of midlaitude $\mathrm{UT} / \mathrm{LS}$ air to the tropical tropospheric $\mathrm{O}_{3}$ budget, additional analyses similar to this study using long-term observational data over other equatorial regions such as the tropical Indian Ocean and Atlantic Ocean are necessary. In addition, a comparison with results of chemical transport models would be significant to examine whether this process has been fully incorporated into the present model calculations.

Acknowledgements. The authors thank two anonymous referees for their constructive comments for improving our work. The trajectory calculation program used in this paper was developed by Y. Tomikawa and K. Sato at National Institute of Polar Research, Japan.

Edited by: M. Dameris 


\section{References}

Baray, J.-L., Ancellet, G., Taupin, F. G., Bessafi, M., Baldy, S., and Keckhut, P.: Subtropical tropopause break as a possible stratospheric source of ozone in the tropical troposphere, J. Atmos. Sol. Terr. Phys., 60, 27-36, 1998.

Baray, J.-L., Daniel, V., Ancellet, G., and Legras, B.: Planetaryscale tropopause folds in the southern subtropics, Geophys. Res. Lett., 27, 353-356, 2000.

Brasseur G. P., Orlando, J. J., and Tyndall, G. S. (Eds.): Atmospheric chemistry and global change, Oxford University Press, New York Oxford, 654 pp., 1999.

Chandra, S., Ziemke, J. R., Min, W., and Read, W. G.: Effects of 1997-1998 El Niño on tropospheric ozone and water vapor, Geophys. Res. Lett., 25, 3867-3870, 1998.

Fishman, J., Watson, C. E., Larsen, J. C., and Logan, J. A.: Distribution of tropospheric ozone determined from satellite data, J. Geophys. Res., 95, 3599-3617, doi:10.1029/89JD02784, 1990.

Fujiwara, M., Kita, K., and Ogawa, T.: Stratosphere-troposphere exchange of ozone associated with the equatorial Kelvin wave as observed with ozonesondes and rawinsondes, J. Geophys. Res., 103, 19 173-19 182, 1998.

Fujiwara, M., Kita, K., Kawakami, S., Ogawa, T., Komala, N., Saraspriya, S., and Suripto, A.: Tropospheric ozone enhancements during the Indonesian forest fire events in 1994 and in 1997 as revealed by ground-based observations, Geophys. Res. Lett., 26, 2417-2420, 1999.

Fujiwara, M., Kita, K., Ogawa, T., Kawakami, S., Sato, T., Komala, N., Saraspriya, S., and Suripto, A.: Seasonal variation of tropospheric ozone in Indonesia revealed by 5-year ground-based observations, J. Geophys. Res., 105, 1879-1888, 2000.

Fujiwara, M., Tomikawa, Y., Kita, K., Kondo, Y., Komala, N., Saraspriya, S., Manik, T., Suripto, A., Kawakami, S., Ogawa, T., Kelana, E., Suhardi, B., Harijono, S. W. B., Kudsy, M., Sribimawati, T., and Yamanaka, M. D.: Ozonesonde observations in the Indonesian maritime continent: a case study on ozone rich layer in the equatorial upper troposphere, Atmos. Environ., 37, 353-362, 2003.

Kita, K., Fujiwara, M., and Kawakami, S.: Total ozone increase associated with forest fires over the Indonesian region and its relation to the El Niño-southern oscillation, Atmos. Environ., 34, 2681-2690, 2000.

Kita, K., Kawakami, S., Miyazaki, Y., Higashi, Y., Kondo, Y., Nishi, N., Koike, M., Blake, D. R., Machida, T., Sato, T., $\mathrm{Hu}$, W., Ko, M., and Ogawa, T.: Photochemical production of ozone in the upper troposphere in association with cumulus convection over Indonesia, J. Geophys. Res., 107, 8400, doi:10.1029/2001JD000844, 2003.

Kiladis, G. N.: Observations of Rossby waves linked to convection over the eastern tropical Pacific, J. Atmos. Sci., 55, 321-339, 1998.

Komala, N., Saraspriya, S., Kita, K., and Ogawa, T.: Tropospheric ozone behavior observed in Indonesia, Atmos. Environ., 30, 1851-1856, 1996.

Kondo, Y., Koike, M., Kita, K., Ikeda, H., Takegawa, N., Kawakami, S., Blake, D., Liu, S. C., Ko, M., Miyazaki, Y., Irie, H., Higashi, Y., Liley, B., Nishi, N., Zhao, Y., and Ogawa, T.: Effects of biomass burning, lightning, and convection on $\mathrm{O}_{3}$, $\mathrm{CO}$, and NOy over the tropical Pacific and Australia in AugustOctober 1998 and 1999, J. Geophys. Res., 107(D3), 8402,
doi:10.1029/2001JD000820, 2002 [printed 108(D3), 2003].

Miloshevich, L. M., Vömel, H., Paukkunen, A., Heymsfield, A. J., and Oltmans, S. J.: Characterization and correction of relative humidity measurements from Vaisala RS80-A radiosondes at cold temperatures, J. Atmos. Ocean. Tech., 18, 135-156, 2001.

Newell, R. E., Wu, Z.-X., Zhu, Y., Hu, W., Browell, E. V., Gregory, G. L., Sachse, G. W., Collins Jr., J. E., Kelly, K. K., and Liu, S. C.: Vertical fine-scale atmospheric structure measured from NASA DC-8 during PEM-West A, J. Geophys. Res., 101, 19431960, 1996.

Oltmans, S. J., Johnson, B. J., Harris, J. M., Vömel, H., Thompson, A. M., Koshy, K., Simon, P., Bendura, R. J., Logan, J. A., Hasebe, F., Shiotani, M., Kirchhoff, V. W. J. H., Maata, M., Sami, G., Samad, A., Tabuadravu, J., Enriquez, H., Agama, M., Cornejo, J., and Paredes, F.: Ozone in the Pacific tropical troposphere from ozonesonde observations, J. Geophys. Res., 106, 32 503-32 525, 2001.

Palmen, E. and Newton, C. W.: Atmospheric Circulation Systems, Academic Press, London, 603 pp., 1969.

Postel, G. A. and Hitchman, M. H.: A climatology of Rossby wave breaking along the subtropical tropopause, J. Atmos. Sci., 56, 359-373, 1999.

Scott, R. K., Cammas, J.-P., Mascart, P., and Stolle, C.: Stratospheric filamentation into the upper tropical troposphere, J. Geophys. Res., 106, 11 835-11 848, 2001.

Stoller, P., Cho, J. Y. N., Newell, R. E., Thouret, V., Zhu, Y., Carroll, M. A., Albercook, G. M., Anderson, B. E., Barrick, J. D. W., Browell, E. V., Gregory, G. L., Sachse, G. W., Vay, S., Bradshaw, J. D., and Sandholm, S.: Measurements of atmospheric layers from the NASA DC-8 and P-3B aircraft during PEM-Tropics A, J. Geophys. Res., 104, 5745-5764, 1999.

Thompson, A. M., Witte, J. C., McPeters, R. D., Oltmans, S. J., Schmidlin, F. J., Logan, J. A., Fujiwara, M., Kirchhoff, V. W. J. H., Posny, F., Coetzee, G. J. R., Hoegger, B., Kawakami, S., Ogawa, T., Johnson, B. J., Vömel, H., and Labow, G.: Southern Hemisphere Additional Ozonesondes (SHADOZ) 1998-2000 tropical ozone climatology 1. Comparison with Total Ozone Mapping Spectrometer (TOMS) and ground-based measurements, J. Geophys. Res., 108(D2), 8238, doi:10.1029/2001JD000967, 2003a.

Thompson, A. M., Witte, J. C., Oltmans, S. J., Schmidlin, F. J., Logan, J. A., Fujiwara, M., Kirchhoff, V. W. J. H., Posny, F., Coetzee, G. J. R., Hoegger, B., Kawakami, S., Ogawa, T., Fortuin, J. P. F., and Kelder, H. M.: Southern Hemisphere Additional Ozonesondes (SHADOZ) 1998-2000 tropical ozone climatology 2. Tropospheric variability and the zonal wave-one, J. Geophys. Res., 108(D2), 8241, doi:10.1029/2002JD002241, 2003b.

Thouret, V., Cho, J. Y. N., Evans, M. J., Newell, R. E., Avery, M. A., Barrick, J. D. W., Sachse, G. W., and Gregory, G. L.: Tropospheric ozone layers observed during PEM-Tropics B, J. Geophys. Res., 106, 32 527-32 538, 2001.

Tomikawa, Y. and Sato, K.: Design of the NIPR trajectory model, Polar Meteorol. Glaciol., 19, 120-137, 2005.

Waugh, D. W.: Impact of potential vorticity intrusions on subtropical upper tropospheric humidity, J. Geophys. Res., 110, D11305, doi:10.1029/2004JD005664, 2005.

Waugh, D. W. and Funatsu, B. M.: Intrusions into the tropical upper troposphere: Three-dimensional structure and accompanying ozone and OLR distributions, J. Atmos. Sci., 60, 637-653, 2003. 
Waugh, D. W. and Polvani, L. M.: Climatology of intrusions into the tropical upper troposphere, Geophys. Res. Lett., 27, 38573860, 2000.

Yonemura, S., Tsuruta, H., Kawashima, S., Sudo, S., Peng, L. C., Fook, L. S., Johar, Z., and Hayashi, M.: Tropospheric ozone climatology over Peninsular Malaysia from 1992 to 1999, J. Geophys. Res., 107(D15), 4229, doi:10.1029/2001JD000993, 2002a. Yonemura, S., Tsuruta, H., Maeda, T., Kawashima, S., Sudo, S., and Hayashi, M.: Tropospheric ozone variability over Singapore from August 1996 to December 1999, Atmos. Environ., 36, 2061-2070, 2002b.
Yoneyama, K. and Parsons, D. B.: A proposed mechanism for the intrusion of dry air into the tropical western Pacific region, J. Atmos. Sci., 56, 1524-1546, 1999.

Zachariasse, M., Smit, H. G. J., van Velthoven, P. F. J., and Kelder, H.: Cross-tropopause and interhemispheric transports into the tropical free troposphere over the Indian Ocean, J. Geophys. Res., 106, 28 441-28 452, 2001. 